\title{
11 The binding power of oaths
}

\subsection{Were oaths always totally binding?}

\section{A.H. Sommerstein}

An oath (at least a formal oath; for informal oaths, see \$13.2) was normally considered, in principle, to be absolutely binding. The story of Glaucus the Spartan (Hdt. 6.86; see $§ 10.2$ ) shows how grave a view could be taken of a man who even so much as contemplated the breach of an oath. It is true that King Leotychidas is presented as telling this story to the Athenians, not in order to dissuade them from committing perjury - for they had not been swearing, or offering to swear, to anything - but to induce them to return to him some Aeginetan hostages, whom he and his late royal colleague Cleomenes had seized from Aegina and entrusted to the Athenians for safe keeping (as the Milesians in his story had entrusted their money to Glaucus). The Athenians had not even denied that the hostages belonged to Sparta; they merely said that they had received them from both the Spartan kings and did not think it right to return them to only one. If the other Spartan king, Leonidas, had been a child, or had been in exile, we might have seen this as a transparent evasion, but neither of these was the case; rather, Leotychidas was trying to bluster the Athenians into complying with his will by putting a quite illegitimate spin on the story so as to suggest that one risked divine retribution if one so much as contemplated (not breaking an oath, but) refusing to return a deposit under any circumstances whatever. The very fact, however, that the story is somewhat beside the point in its context shows that it reflects a view that was widespread in Herodotus' time.

The same conclusion may be drawn from the delicacy that was shown in the framing of the oath of loyalty to democracy that was prescribed by the decree of Demophantus after democracy was restored at Athens in 410 BC (Andocides $1.96-8 ;^{1}$ see S\&B 130-1). Before and during the oligarchy of the Four Hundred, a year earlier, various anti-democratic conspiracies (see S\&B ch. 6) had been hatched at Athens and elsewhere, and many of these had been cemented by oaths - or at least no one, other than the conspirators themselves, could be sure that they had not been. What could be done about groups that might have sworn to each other - as, according to Aristotle, oligarchs in some states still did in his

1 On the authenticity of this decree, denied by Canevaro \& Harris 2012, see now Sommerstein 2014. 
time $^{2}$ - "I will bear ill-will to the demos and do it any harm I can"? In the end, to the oath that was imposed on all Athenian citizens, committing them to put to death anyone who in the future established, or took part in, any regime but a democratic one, and to reward and honour anyone who killed such a traitor to democracy or died in an attempt to do so, there was added a further clause:

And all oaths that have been sworn, at Athens or in the camp or anywhere else, in opposition to the Athenian people, I dissolve and release.

This clause may seem at first sight to subvert quite radically the principle of the binding force of oaths. It does nothing of the kind. It speaks very carefully not, as one might expect, of "oaths that I have sworn", but of "oaths that have been sworn"; ${ }^{3}$ and the verb "release" (aphiēmi) was widely used in legal contexts to refer to an act whereby "a real or potential plaintiff [gave] up what would otherwise be his right, e.g. to collect what [was] owed to him or to prosecute someone who [had] committed an offence against him". ${ }^{4}$ The citizen, in other words, was not being required to renege on his own oaths previously sworn; he was being required to "[give] up what would otherwise be his right" to have others remain true to the anti-democratic oaths which they had previously pledged to him. If all participants in a sworn conspiracy were to give up that right, the oaths of the conspiracy would automatically melt away. ${ }^{5}$

The Demophantus oath shows, as one would expect, that a sworn pledge could at any time be modified, or even abrogated, by the consent of those for

2 Arist. Pol. 1310a7-10.

3 This is, according to $T L G$, the only occurrence of the third-person plural verb ó $\mu \omega \dot{\mu} \mu$ ovtat "(they) have been sworn" in any ancient Greek literary text (or document quoted therein) whatsoever. Nor does it occur in any inscription in the PHI epigraphic database (http://epigraphy. packhum.org/inscriptions/main; accessed 30 January 2014).

4 Carey \& Reid 1985, 117.

5 This ingenious device had, however, a loophole: what if some of the participants in a conspiracy were not Athenian citizens, and so did not take the Demophantus oath? Those who did take the Demophantus oath would then not have been released from their earlier pledges, and so would find themselves bound by two contradictory oaths, one democratic and one anti-democratic. At Athens this loophole may well have been only theoretical, but "in the camp" - in other words, at Samos, where the fleet was based - it would have been of the greatest importance, since in 411 Athenian and Samian oligarchs had been working closely together (Thuc. 8.63.3-4, 8.73). The most likely explanation is that a similar oath of release had already been taken at Samos after the restoration of democracy there (cf. Thuc. 8.73.6). It should be added that an oath of reconciliation taken at Dicaea between 365 and 359 (see Voutiras \& Sismanides 2007 and S\&B 141-3) does include a repudiation by the swearer of any previous oaths he had sworn to the contrary. 
whose benefit it was made; provision for such modification was often explicitly made in sworn treaties, ${ }^{6}$ but it must always have been implicit in any case. It also shows that its drafter thought an oath could not be abrogated without such consent, not even an oath to commit what the swearer afterwards came to regard as a crime deserving instant death.

A remarkable story from the mid fourth century shows us a military commander going so far as to launch an attack against men on his own side, with fatal consequences, and risk the anger of the most powerful men in his world, rather than break an oath he had given to the enemy. The central figure of this story (D.S. 16.49.1-6) is Lacrates, a Theban who in 350/49 was commanding the Boeotian division of the mixed Greek forces assisting Artaxerxes III of Persia in his attempt to reconquer Egypt, whose rebellious king - Nectanebos II, the last of all the pharaohs - also had many Greeks in his service. Lacrates was besieging Pelusium, at the eastern extremity of the Nile delta, and the city was being valiantly defended by Nectanebos' Greek troops until they learned that their king and his Egyptian forces had withdrawn to Memphis, more than a hundred miles upstream. They then sent envoys to negotiate with Lacrates, who gave them a sworn pledge that if they surrendered Pelusium to him they would all be conveyed back to Greece with whatever they could carry with them. On this they surrendered the fortress, and Artaxerxes sent his trusted minister and general, Bagoas, with non-Greek troops, to take it over. At the gates of Pelusium these troops met the departing Greeks and began to plunder their effects; the Greeks "called loudly on the gods who had witnessed the oaths", and Lacrates at once attacked Bagoas' men, put them to flight and killed several of them. Bagoas fled to Artaxerxes and made an accusation against Lacrates; but the King's judgement was that Bagoas' men had got their just deserts, ${ }^{7}$ and he himself condemned to death those who had been guilty of the robbery.

\footnotetext{
6 As in the Peace of Nicias in 421 (Thuc. 5.18.11) and the subsequent Athenian-Spartan alliance (Thuc. 5.23.6); see Kozak in S\&B §10.5. The enabling clause in the latter read: "If it seems good to the Lacedaemonians and the Athenians to add or to take away anything regarding the alliance, then whatever seems good to them shall be no breach of oath for either." In the peace treaty it ran: "If either party has forgotten something, on any point, about anything, it will not be a breach of oath for both parties to change whatever seems best to both parties, after just consultation, to the Athenians and to the Lacedaemonians." This clause in fact caused trouble later on, since Sparta's allies complained that it gave Sparta, in agreement with Athens, the right to amend the treaty without consulting them (Thuc. 5.29.2-3); Sparta could have responded, had she wished, that the time to make such complaints was before the treaty had been concluded and sworn to, not after.
}

7 This implies, or ought to imply, that the men were aware of the terms of the agreement made 
Could it ever be right to deliberately break an oath ${ }^{8}$ The issue receives a theoretical discussion in the sophistic work known as the Dissoi Logoi (3.6-7) from the late fifth or early fourth century, in the course of an argument designed to show that there are extreme circumstances in which the most sacred duties can come into conflict and that it may be right (e.g.) to rob a temple if its treasures are needed to fund the defence of Greece against barbarian invaders, or to break and enter a public building if, during a period of civil strife, one's father is confined there by a hostile faction and under sentence of death. On the topic of perjury, the author considers the following case:

If someone has been captured by the enemy in war, and promises on oath that if released he will betray his city, would he be doing right to keep his oath? For my part, I think not; he should rather save his city, his friends and the sanctuaries of his fathers by breaking it.

One might reasonably see this as a very artificially devised problem, not least because such a ploy could be used only once - if it became known that prisoners of war were taking oaths of this kind with no intention of keeping them, their captors would at once cease giving them the opportunity. It is not surprising that we know of no such instance in real life. And it is striking that the ingenious author of the Dissoi Logoi cannot think of any more plausible scenario. He presents a whole series of other examples in which conduct which would normally be thought criminal or impious could reasonably be regarded as entirely justifiable; two of these are mentioned above, and all the others are credible situations in which a contemporary might well have agreed with the author's verdict. ${ }^{9}$ Only in the case of perjury is he forced to imagine a situation which one cannot seriously envisage arising in reality. And except in one type of case which will be discussed presently, no text from the archaic or classical period tells us of any instance in which a person plainly violated a formal oath and got away with it. ${ }^{10}$

with Lacrates. Artaxerxes and Bagoas will certainly have known of these terms; Bagoas will doubtless have assured the King that he had ordered his men not to molest the Greeks departing from Pelusium - but whether he actually did so order is perhaps another matter.

8 Torrance in §12.1.2 discusses two passages in which Euripidean characters seem to say that oaths taken under duress are not binding, but rightly regards them as suspect evidence.

9 Some of them are echoed in Pl. Rep. 331c-d and especially in Xen. Mem. 4.2.12-19. To enslave the entire population of a captured city (Dissoi Logoi 3.5) would not, one hopes, be regarded as justifiable by anyone today, but our author clearly expects that his readers, at least in certain circumstances, would see nothing wrong with it; it was what "the Corinthians and Thebans especially, but also many of the other Greeks" wanted to do to Athens in 404 (the Spartans vetoed the proposal: Andoc. 3.21; Xen. Hell. 2.2.19-20).

10 Unless one counts the Sausage-seller in Aristophanes' Knights (296-8, 417-28, 1239); but for 
The only situation in which a Greek could realistically conceive of an oath not being binding would be if the god in whose name the oath was taken were to be overruled by a more powerful god. This possibility is raised twice in The Eumenides, the third play of Aeschylus' Oresteia trilogy of $458 \mathrm{BC}$, in which oaths are a major theme (see §2.1) - both times by Apollo. After Apollo has helped Orestes to escape from the Erinyes and make for Athens where he will stand trial, the Erinyes angrily accuse him of aiding a matricide, and an argument develops during which he asks them why they are not equally indignant about the murder of a husband (like Agamemnon) by his wife. They reply (Eum. 212) that Clytaemestra was not blood-kin to her victim; to which Apollo rejoins (213-18):

Truly you have held in utter contempt the pledges of Hera Teleia [Hera as goddess of marriage] and of Zeus, and treated them as being of no account; and Cypris [Aphrodite] too is cast aside in dishonour by this argument, she from whom come the closest, dearest ties that mortals have. The bed of a man and a woman, when hallowed by destiny, is something mightier than an oath, and Justice stands sentinel over it.

The reference to oaths comes as something of a surprise, since nothing had been said about them in the argument up to this point. Possibly we are meant to think back to a scene in the previous play, The Libation Bearers (977-9), when Orestes, standing over the slain corpses of Clytaemestra and her lover Aegisthus, said sarcastically that they had been true to their mutual oath to kill Agamemnon and to die together. That was an oath to violate the sanctity of marriage, and as such, Apollo seems to be saying, it was sworn in defiance of Zeus, Hera and Aphrodite and should be regarded as null and void.

To reach this conclusion, however, takes quite a bit of recollection and ratiocination, and many spectators may merely be somewhat puzzled by the idea that anything could be "mightier than an oath". They will probably be something more than puzzled when Apollo brings the same idea up again, about four hundred lines later. Orestes is being tried at Athens by a tribunal whose members, like all Athenian judges, have sworn to give a just decision (Eum. 483, 489), and Apollo, acting as his witness and advocate, states unequivocally (Eum. 614-21) that in killing his mother Orestes had acted with justice, because he was obeying a command by Apollo which, like all Apollo's oracular utterances, had been given on the instructions of Zeus.

one thing it is crucial to that play that so great a villain as Cleon can only be overthrown by a yet greater villain, and for another thing the only act of perjury by the Sausage-seller which is described in detail (417-28) may actually be a case of "sidestepping” (see §10.3). 
I tell you solemnly [he continues] to understand well how strong is this plea of justification, and I tell you to follow the counsel of the Father; for an oath can in no way be stronger than Zeus.

This time there can be little doubt which oath Apollo is referring to. Since he is advising Orestes' judges on how they should vote, the only relevant oath is the oath which they have taken as judges. We have not been told the terms of this oath, nor by which gods it was sworn, but Athena's words later in the trial (674-5) about their voting "in accordance with their honest opinion" suggest that we are to think of the ordinary oath of the Athenian juryman, which included a clause to this effect (see S\&B §5.4). ${ }^{11}$ Apollo, then, is saying what no real speaker would ever dare to say in the Athenian courts: he is saying that the judges should ignore their judicial oath. ${ }^{12}$ He can say this, he claims, because the will of Zeus overrides any oath - and that makes theological sense: Zeus, as the supreme god, will be able to prevent any other deity from punishing a breach of oath of which he, Zeus, approves, and will presumably wish himself to punish anyone keeping an oath that runs contrary to his will.

But is the will of Zeus really what Apollo says it is? Apollo is not the only child of Zeus who is involved in the dispute over Orestes' actions, and who is on stage at this moment. As he himself points out (662-6), Athena is also a child of Zeus, and indeed more fully a child of Zeus than Apollo is, for she had no mother (cf. 736-8). She gives a preliminary hint of her position by alluding at 674-5, as we have seen, to the phrasing of the Athenian judicial oath. Then she delivers a speech announcing the establishment of the Council of the Areopagus, praising its justice, its incorruptibility, and its role in ensuring the political stability of Athens, and decrying any innovations in its laws; ${ }^{13}$ and at the end, turning to its founder members, she says:

Now you must rise, deliver your votes, and decide the case, respecting your oath. I have said my say (708-10).

11 And was sworn by Zeus and Apollo (together with Demeter)!

12 He therefore cannot say at 679-80, as many editors make him do, that the jurors should "respect their oaths" when they vote; rather, these words must be spoken by the chorus of Erinyes (or by their leader on their behalf) and Apollo given lines 676-7 which make no reference to the oath.

13 This section - by far the greater part - of Athena's speech is explicitly addressed to "my citizens for the future" and is obviously relevant to the politics of Aeschylus' own day; whether it is designed to promote a particular political stance (and if so, which) is a controversial question that need not be gone into here (see Sommerstein 1989, 216-18). 
A very plain rap over the knuckles for Apollo, and that even though Athena herself accepts (797) that his oracle did come from Zeus, and even though she will in the end herself vote for Orestes' acquittal (734-41). The daughter of Zeus is in effect telling the judges - and the Athenian audience too - that the will of Zeus does not override an oath, that, on the contrary, it is the will of Zeus that oaths shall always be kept (it is not for nothing that one of Zeus's titles is Horkios, the oath-god). And presumably we are meant to suppose that they do take her words to heart, as any good citizen would. As they vote, Apollo and the Erinyes wrangle inconclusively; and when the result is declared, it is a tie ${ }^{14}$ - which, by a ruling Athena has previously given, means that Orestes wins. In considering Athena's subsequent successful efforts to conciliate the Erinyes, now more furious than ever at having been, as they see it, cheated and denied justice by the "younger gods", it is worth remembering that but for Athena's refusal to let Apollo use the name of Zeus to overawe and browbeat the judges, but for her insistence that they must respect their oath, the prosecution might well not have got a single vote. The Erinyes ${ }^{15}$ may, and do, resent the fact that because of Athena they lost the case despite receiving half the votes; but it was also because of Athena that they received as many as half the votes in the first place.

\subsection{The oaths of lovers}

\section{A.H. Sommerstein}

There is just one category of oaths that were traditionally regarded as not binding, as Pausanias is made to explain in Plato's Symposium (183b). He is describing the extraordinary licence given by Athenian custom to lovers (that is, adult male admirers of handsome boys or youths), who are permitted and indeed encouraged to do many things which in any other social context would bring disgrace on them and to be "willing to undergo a degree of servitude that no slave would tolerate”. In particular,

the most extraordinary thing of all - or so most people say - is that if he swears an oath, he alone will be forgiven by the gods if he transgresses it, for they say that a lover's oath is no oath: such total licence have both gods and men allowed to the lover.

14 It is, again, a controversial question, and again one that does not need to be discussed here, whether this equality of votes is exclusive or inclusive of Athena's own vote; see Sommerstein 1989, 222-6.

15 Who had been midwives to the oath-god Horkos (Hesiod, Works and Days 803-4) and in whose name oaths were taken in homicide and other trials held on the Areopagus (see S\&B §5.14). 
The same theme appears in the speech that Socrates extemporizes in Plato's Phaedrus (237b-241d) purporting to prove that a boy would be better advised to grant his favours to a man who was not in love with him than to one who was. He considers (240e-241c) what happens to a lover who has successfully courted his beloved, "making promises with many oaths and beseechings", and who then, his passion fading, "becomes a different person", refuses to make any return for the favours he has received or to fulfil his earlier oaths and promises, and leaves his former beloved "indignantly appealing to the gods", not realizing that he would have been far better off giving himself to a man governed by reason rather than passion. It is not actually stated that the boy's indignant appeals to the gods go unanswered, but it would vastly weaken the argument of the speech if it were assumed that the ungrateful lover could expect divine punishment. ${ }^{16}$

Despite what might be gathered from Pausanias' speech, the principle that "a lover's oath is no oath" was by no means a purely Athenian one. As early as the Catalogue of Women ascribed to Hesiod (and probably in fact composed in the sixth century) it had been dignified with a mythical aetiology (Hes. fr. 124): when Zeus raped or seduced Io, who was a priestess of Hera, and was caught by Hera, ${ }^{17}$ he swiftly turned Io into a white cow and then swore that he had not had intercourse with her; ${ }^{18}$ "and because of this he made oaths free of penalty (?) for men when they were concerned with the secret doings of Cypris".

Quite apart from this mythical warrant for the principle, one can perceive a further theological rationale for this immunity from punishment granted to "lovers' oaths". Notoriously, the gods themselves were vulnerable to sexual desire, or, otherwise put, "inferior to Eros" (or Aphrodite) (Hes. Thg. 120-2; Soph. Trach. 441-3, Ant. 787; Eur. Tro. 948-50; Ar. Clouds 1080-1), and they would not be able to punish mortals for obeying the will of a deity to whose power they themselves were subject.

But even the exemption of the lover's oath should perhaps be regarded as more of a humorous catch-phrase than a genuine social fact. It makes only one appearance in archaic or classical literature outside the passages already cited, in a line of comedy (Philonides fr. 7) in which someone, doubtless a jilted woman, says "I think the oaths of adulterers are written in ash" - which, be it noted, is

16 Cf. also Pl. Phil. 65c.

17 Presumably not in the act (which he could otherwise scarcely have denied) but in compromising circumstances very shortly afterwards.

18 It is not clear whether this sworn assertion is to be taken as a direct lie or as a "sidestep" (Zeus swearing that he had not had intercourse with the cow): the aetiology implies the former alternative, but the latter would make the transformation more clearly relevant in this context. 
a parody of a line of Sophocles (fr. 811) about the oaths of women. ${ }^{19}$ It would be very convenient for Jason in Euripides' Medea to excuse by this principle his breaking of the oaths he swore to Medea, but he never does: her repeated accusations of perjury he simply ignores. And when the young man Moschion, as he tells us in Menander's Samia (50-3), visited the mother of the girl he had made pregnant and swore that he would marry her as soon as her father returned from abroad, it clearly did not occur either to him or to his future mother-in-law - and one may well doubt if it would have occurred to any member of the theatre audience - that his oath was actually worthless. In practice, even in matters of love, an oath was an oath was an oath.

\subsection{The tongue and the mind: responses to Euripides, Hippolytus 612}

\section{I.C. Torrance}

The absolutely binding power of an oath is well illustrated by the case of Euripides' Hippolytus in the eponymous play. The angry statement he makes at Hipp. 612 - "It was my tongue that swore, but my mind is unsworn" - is uttered when his stepmother Phaedra's nurse reminds him that he has been bound by an oath of secrecy which he should not break (611). The line, which seems to have gained immediate and unique notoriety, as discussed below, is spoken after Hippolytus has been told of Phaedra's desire for him. Furious, he threatens to reveal the outrageous secret in public, and momentarily contemplates breaking his oath with his statement at 612 . He soon reveals, however, just forty-five lines later, that his reverence for the gods will make him refrain from breaking the oath which he took in their name (657). When Theseus returns, Hippolytus again wonders whether he should unseal his lips (1060) in frustration at Theseus' refusal to believe him, but decides that it would have no purpose since he would at once violate his oath and fail to convince Theseus (1061-3). Hippolytus' piety in relation to oaths is even confirmed by Artemis in the exodos where she praises Hippolytus not only for rejecting the Nurse's proposal, but also for keeping his oath of silence even in the face of Theseus' slanderous accusations (1306-9). Having

19 There may be another instance in a fragmentary erotic poem by Bacchylides (fr. 19) where a man who has "fled to his dear wife in nothing but his chiton" may or may not be described (presumably by his mistress) as [ep]iorkos. 
been duped into swearing a blind oath, Hippolytus is prevented from revealing the truth that would exonerate him.

It is likely that the oath of silence sworn by Hippolytus, and his subsequent expression of frustration at being trapped by it, were inventions of Euripides. ${ }^{20}$ As Barrett observes, the implication at Hipp. 612 that Hippolytus might break his oath, however briefly this suggestion is made, is "essential to the play" since it leads Phaedra to believe that Hippolytus "will ignore the oath; and it is in that belief (689-92) that she plots his destruction". ${ }^{21}$ The crucial component to that plot is the suicide letter in which Phaedra accuses Hippolytus of having raped her. ${ }^{22}$ Hipp. 612 is thus central to the development of the tragedy, and although Hippolytus does not break his oath, the fact that he considers doing so seems to contribute to his fate. Judith Fletcher observes that a second oath of silence in this play is also part of the orchestration of Hippolytus' downfall, namely the oath of the chorus to keep Phaedra's desire for Hippolytus secret (713-14), ${ }^{23}$ and oaths of silence seem to be important in Phaedra's Cretan background. A fragment of Bacchylides (fr. 26.8) includes a reference to Phaedra's mother Pasiphae telling Daedalus of her illness (i.e. her lust for the bull) and making him swear an oath, presumably one of secrecy.

Hippolytus does not break his oath of secrecy, but as we saw above in the case of Glaucus the Spartan the mere contemplation of perjury could be enough to condemn his progeny to the perjurer's punishment of extinction (\$10.2). Hippolytus' fate might also be read, in part at least, as a result of his momentary temptation to perjure himself. Tragic characters often come to their doom through a complex web of causation involving both human and divine agency. In Aeschylus' Agamemnon, for example, Agamemnon's death can be read as the result of his involvement with Greek impieties against the gods at Troy, but it is also caused by his own decisions, and of course by Clytaemestra's revenge on him for murdering their daughter. ${ }^{24}$ Similarly, in Sophocles' Oedipus the King, the fate of Oedipus is a result of his own actions, but these seem to be guided by divine forces. ${ }^{25}$ Hippoly-

20 It is likely that an oath of secrecy featured also in Euripides' lost first Hippolytus play; see Barrett 1964, 11, and Talboy \& Sommerstein 2006, 259-60 with n.31.

21 Barrett 1964 ad 612.

22 On the importance of the suicide letter see esp. Segal 1992 and Torrance 2013, 146-52.

23 Fletcher 2012, 191-2.

24 On Agamemnon's decision-making see Lloyd-Jones 1962, Hammond 1965, Peradotto 1969, Dover 1973, Edwards 1977, Konishi 1989; on the importance of Zeus in Aeschylus see Lloyd-Jones 1956; on the extent of Clytaemestra's responsibility for the murder of Agamemnon see O'Daly 1985.

25 On the role of the gods in Sophocles' Oedipus the King, see Segal 1995, 180-98 and cf. Segal 
tus' destruction in Euripides' extant play also comes about through a combination of human and divine agency. Hippolytus is impious in his rejection of Aphrodite who plans his downfall, but Phaedra, her Nurse, the chorus, Theseus, Poseidon, and Hippolytus himself, all play a part in events. Segal argued that the manner of Hippolytus' destruction is connected not only to Theseus' invocation of Poseidon's curse upon Hippolytus but also to the fulfilment of the self-curse included in Hippolytus' oath to Theseus in which he protests his innocence (Hipp. 1025-31). ${ }^{26}$ Hippolytus invokes Zeus Horkios and the Earth and states that he never touched his father's marriage-bed nor could even have conceived of doing so. Unusually for an oath, as Segal observes, the potential curse for perjury is expressed in very specific terms, namely that he should perish without honour, nameless, and that neither the sea nor the earth should receive his flesh when he is dead if he has been a base man. ${ }^{27}$ Segal suggests that since Hippolytus is destroyed at a point where the land is hidden, "he is in a sense 'received' by 'neither sea nor land', and the hypothetical self-curse (oath of innocence) and ostensible punishment (proof of guilt) are fused." ${ }^{28}$ Only the intervention of Artemis can bring closure for Hippolytus. She is the one who describes him as being in the gloom "under the earth" (Hipp. 1416) and who predicts posthumous honours for him (1423-30). She is also the one who praises him for keeping his oaths (1305-9), but she passes over in silence the potential loophole for perjury proposed by Hippolytus at 612 , and it is clear, as Segal has demonstrated, that oath and curse are inextricably intertwined in this play.

The fact that a mere contemplation of breaking one's oath could be viewed as equivalent to perjury is supported by the various appropriations of Hippolytus 612 in Aristophanes and in Plato, since each adaptation carefully avoids replicating the situation in Hippolytus. Aristophanes parodies Hipp. 612 three times in his extant plays, each time at the expense of the character Euripides. In Women at the Thesmophoria, the Inlaw has agreed to dress up as a woman and attend the women-only festival of the Thesmophoria on Euripides' behalf. But he gets Euripides to promise to rescue him if anything goes wrong. Euripides first of all swears an oath "by the Aether, the dwelling-place of Zeus" (Thesm. 272), but the Inlaw feels that this is not a serious enough invocation and Euripides then swears

1981, 248: "Oedipus' tragedy...asks whether human life is trapped in a pattern of its or own others' making."

26 Segal 1972.

27 Segal 1972, 169-70 shows that in a small number of comparable cases "the situation is unusually dramatic" (169).

28 Segal 1972, 170. 
"by all the gods, the whole lot!" (274). ${ }^{29}$ The Inlaw then asks him to remember

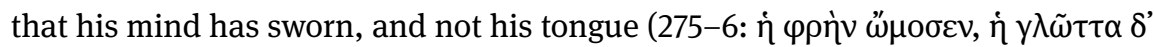
oủ ó $\left.\mu \omega^{\prime} \mu \kappa^{\prime}\right)$. The parody of Hipp. 612 is clearly designed to prevent Euripides' character from wriggling out of his oath by using the line "my mind is unsworn" but the line is never used by Euripides who later in the play perseveres and succeeds in rescuing the Inlaw, despite two failed attempts. This humorous reversal of the original line takes stock of Hippolytus' implication that there is a distinction between an oath of the mind and an oath of the tongue, where the former would be more binding than the latter. ${ }^{30}$ Of course, as the events of Euripides' Hippolytus demonstrate, any such distinction is illusory and the use of the line from Hippolytus against the character of Euripides is exploited for purely comic purposes. $^{31}$

In Frogs, Hipp. 612 is parodied twice. The first reference comes at the beginning of the play when Dionysus expresses his intention to find a really potent poet and bring him back to Athens from the Underworld. Heracles asks him to explain what he means by "potent" (gonimon), and Dionysus replies that he means a poet who can say daring things like ... "a mind that does not wish to swear over sacrificial victims, and a tongue that perjures itself separately from the mind" (Frogs 101-2). The adaptation of the original text is once again interesting. Line 102 articulates the element of perjury that is implicit but unexpressed in Hipp. 612, and the attempt to create an apparent escape clause from within a completely binding agreement is echoed in the previous line through the image of the mind (but presumably not the tongue) being unwilling to swear over sacrificial victims. This confirms what we saw in ch. 6, namely that including animal sacrifice as part of an oath ceremony was a way of adding additional sanctity or, to put it another way, of making the oath more binding. As it happens, Dionysus in Frogs ultimately decides not to bring Euripides back to Athens after being won over by Aeschylus. Euripides protests and tells Dionysus to remember the gods by whom he swore that he would take Euripides home (1469-70). Dionysus had not, in fact, "sworn" to take Euripides home, though he had expressed a strong desire to initially, but he is unfazed by Euripides' accusation and simply replies “'Twas but my tongue that swore; I'm choosing Aeschylus" (1471). ${ }^{32}$

29 On the problematic nature of swearing oaths by Aether, see $\S 5.3$.

30 Cf. Dillon 1995, 142, who suggests that the line is "scandalous because it tempts the audience to question the validity of the external oath to fix inner truth".

31 Dillon 1995, 143-4, also suggests that the Aristophanic parodies of Hipp. 612 are essentially humorous.

32 This is a rare example of what we have termed a "Sophoclean" oath outside Sophocles, and is discussed in more detail in $§ 5.2$. 
Although these passages seem to present the line as a clever means of committing perjury, it is never actually used by anyone who has sworn a related oath. In this respect Aristophanic usage reflects the Platonic dialogues where the passage is referenced not in relation to perjury per se but as a means of escaping self-contradiction and reneging on an unsworn agreement. In Theaetetus, a dialogue whose subject matter is an attempt to define the nature of knowledge, no final definition is reached, but several conclusions are established concerning what knowledge is not. During this pursuit, Socrates manages to trick the young Theaetetus into contradicting himself (154c-d). Socrates gives the example of comparing, say, six dice with four, and gets Theaetetus to agree that six is more than four and that there is no other way of looking at it. He then asks Theaetetus what he would say if someone asked him "Can anything become more other than by being increased?" Theaetetus, it seems, fails to notice the shift from "being" to "becoming". He has just said that six dice are more than four (where there had been no reference to increase), but now seems to think that he will be forced to agree that nothing can be more (rather than become more) unless it is increased. ${ }^{33}$ He replies as follows: "If I were to answer with reference to the last question, I would say no, but if I answered with reference to the previous question, I would say yes, to guard against contradicting myself." Socrates replies that if Theaetetus says yes, the situation will be like that in Euripides - his tongue will be incontrovertible, but not his mind. The language of swearing is notably absent here, as in the Symposium, where Socrates alludes to Hipp. 612 to excuse himself from continuing with the eulogy of Eros. Once he realises that the eulogist's job entails lying, he withdraws from the discussion by saying that it was merely his

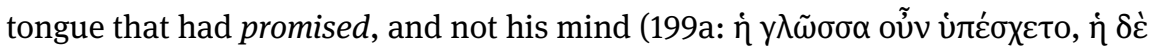

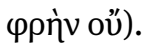

None of the texts in which the line is referenced, then, actually include any associated perjury nor contemplation thereof by the swearer. Nevertheless, Aristotle tells us that Hipp. 612 led Euripides to be accused of impiety by a certain Hygiaenon, and that Euripides responded by saying that he had already given his account ( $\delta \varepsilon \delta \omega \kappa \varepsilon ́ v \alpha ı ~ \lambda o ́ y o v)$ at the Dionysia and that his accuser was wrong to bring decisions from the Dionysiac contest into the law courts (Rhetoric 1416a31-2). It is not clear exactly what is meant by Euripides giving his account of the line at the Dionysia: it may simply suggest that by producing the play at the Dionysia he had already submitted himself to the judgement of the audience and the contest judges. Avery argues that Hygiaenon "made the line notorious

33 The distinction is one which is important for Plato, as, for example, in the discussion of Simonides PMG 542 in the Protagoras 339b-347a. 
by twisting its meaning to suit his own purposes", and it may well be that Hygiaenon's accusation was what created, or at least increased, the line's infamy. ${ }^{34}$ Certainly the most obvious defence against the accusation is that Hippolytus dies a gruesome death after imagining a distinction which might excuse perjury, suffering as do other tragic characters who commit explicit perjury (on which see $\S 12.1)$. It also seems that the judges enjoyed the play since they awarded Euripides first prize in $428 \mathrm{BC}$ for the production which included this Hippolytus, one of only four first prizes won in his lifetime. ${ }^{35}$

It is ironic, as Mikalson has noted, that the line should have brought charges of impiety against Euripides when it is "spoken by a character proven, in all of tragedy, most loyal to oaths in the most trying and tragic of circumstances". ${ }^{36}$ The unique reception of this line, however, shows that the sentiment expressed in Hipp. 612 was dangerous. Subsequent adaptations meticulously avoid the precise situation of the original, and the tragedy as a whole demonstrates that oaths are binding in thought, as well as in speech. When Hippolytus states that his mind is unsworn, he effectively denies that his oath exists, in part at least, as the result of a thought process. He suggests that the oath was taken only as a speech act and not as a conscious decision, but in practice it is not possible to separate these two aspects of an oath. It is true, of course, that he swore the oath blind, but the fact remains that he agreed to swear it nonetheless. For all his pious reverence for Artemis, Hippolytus' complete disregard for Aphrodite shows that he does not understand appropriate religious behaviour. Aphrodite openly plans his destruction and Artemis cannot save him. Similarly Hippolytus does not seem to realize that his momentary rejection of an oath, even in thought, might contribute to the complex web of destruction in which he becomes entangled.

34 Avery 1968, 24.

35 Gibert 1997 and Hutchinson 2004 question whether the extant Hippolytus (rather than the lost Hippolytus) was the one which was awarded first prize, but I agree with Barrett 1964, 13 and Talboy \& Sommerstein 2006, 266-9 that the extant Hippolytus must have been the later of the two plays and the play which won first prize in 428 (cf. Torrance 2013, 146-52).

36 Cf. Mikalson (1991) 86. 